\title{
Kosttilskudd med jern ved jernmangel
}

\begin{abstract}
BAKGRUNN Lite jern i kosten kan gi jernmangel og mild jernmangelanemi hos friske individer. Kvinner er mer utsatt enn menn på grunn av jerntapet ved menstruasjonsblødningene. Vi sammenliknet effekten av en lav dose jern gitt som kosttilskudd med effekten av en høy farmakologisk jerndose hos ellers friske individer med jernmangel og lett jernmangelanemi.
\end{abstract}

MATERIALE OG METODE I en randomisert, dobbeltblind studie, utført i perioden 2000-01, fikk 73 kvinner og tre menn med jernmangel enten 27,6 mg jern bestående av ferrofumarat beriket med $13 \%$ hemjern eller $100 \mathrm{mg}$ ferrosulfat daglig i 12 uker. Blodprøver ble analysert fire ganger i løpet av behandlingen.

RESULTATER Median ferritinverdi økte med henholdsvis $13 \mu \mathrm{g} / \mathrm{l}$ og $7 \mu \mathrm{g} / \mathrm{l}$ i høydose- og lavdosegruppen. Økningen i ferritinnivå var signifikant større i høydose- enn i lavdosegruppen ( $p<0,001)$. Når det gjaldt hemoglobin ( $\mathrm{Hb}), \mathrm{s}$-jern og s-jernbindingskapasitet var det ikke statistisk signifikant forskjell i endring mellom gruppene. Median $\mathrm{Hb}$-verdi økte med 0,4 g/ $100 \mathrm{ml}$ i begge grupper. $58 \%$ i høydosegruppen og $35 \%$ i lavdosegruppen fikk gastrointestinale bivirkninger. Fire deltakere i høydosegruppen og én i lavdosegruppen avbrøt behandlingen på grunn av bivirkninger.

FORTOLKNING Tilskudd av lavdosejern er tilstrekkelig for å øke jernlageret ved ernæringsbetinget jernmangel hos friske individer og for å optimalisere hemoglobinnivået. Høydosejern ga størst økning av jernlageret, lavdosejern ga færrest bivirkninger.

Lavt inntak av jern er en vanlig årsak til små jernlagre og jernmangel (1). Kvinner er mer utsatt enn menn på grunn av jerntap ved menstruasjonsblødninger og svangerskap. To norske studier har vist at kvinner i aldersgruppen 20-55 år har små jernlagre, med en gjennomsnittsverdi for s-ferritin på rundt $30 \mu \mathrm{g} / \mathrm{l}$, og at vel en femdel lider av jernmangel, definert som tomme jernlagre med $\mathrm{s}$-ferritin $<15 \mu \mathrm{g} / 1(2,3)$. Dette gir økt risiko for jernmangelanemi. Hos menn og hos kvinner etter menopausen er sykdom som fører til nedsatt jernabsorpsjon og blødning fra mage-tarm-kanalen en viktig årsak til jernmangel (4).

I retningslinjer for å forebygge og behandle jernmangel og jernmangelanemi anbefales farmakologiske doser fra $120 \mathrm{mg}$ til opp mot $600 \mathrm{mg}$ jern daglig $(5,6)$. Så høye doser av jernsalter kan føre til gastrointestinale bivirkninger og dårlig behandlingsetterlevelse $(7,8)$. Ved ernæringsbetinget jernmangel og mild jernmangelanemi kan det derfor være formålstjenlig å gi en lavere dose jern. Flere studier har vist at et daglig tilskudd på 18-27 mg jern forbedrer jernstatusen hos kvinner (9-12). Tabletter bestående av ferrofumaratjernsalt beriket med $11-13 \%$ hemjern hadde $\mathrm{i}$ disse studiene gunstigere effekt enn tilsvarende dose rent jernsalt. Et savn ved tidligere studier er manglende sammenlikning med større, farmakologiske jerndoser som tradisjonelt brukes ved behandling av jernmangel. Det er derfor uklart om en lav jerndose gitt som kosttilskudd (13) kan erstatte en høyere dose når målet er å restituere jernlageret og korrigere en lett jernmangelanemi.

Hensikten med denne studien var å sammenlikne effekten av en lav dose jern gitt som kosttilskudd med en større farmakologisk jerndose hos ellers friske individer med jernmangel og lett jernmangelanemi.

\section{Materiale og metode}

Deltakerne i studien, som ble utført i perioden 2000-01, var friske individer som for første gang meldte seg som blodgivere ved blodbanken, Haukeland universitetssjukehus, og som, bortsett fra dårlig jernstatus, fylte medisinske krav for å bli godkjent som blodgiver. Aktive blodgivere og gravide ble ikke inkludert i studien. I løpet av ett år ble 604 kvinner og 506 menn screenet for jernmangel og jernmangelanemi, definert med grenseverdier for hemoglobin og s-ferritin som vist i ramme $1(14,15)$.

Figur 1 viser antall deltakere som ble inkludert i en 12 ukers behandlingsstudie med sammenlikning av lavdose- og høydosejern. Én kvinne i hver gruppe hadde sluttet å menstruere. Tre kvinner som opprinnelig oppfylte inklusjonskriteriene og hadde samtykket i å delta, ble ekskludert før studien startet på grunn av graviditet, forhøyet CRP-nivå og manglende oppmøte.

Studien ble utført som et kontrollert, dobbeltblindt forsøk. Randomiseringen ble gjort ved hjelp av en randomiseringstabell i omniSTAT (Design and data analysis in clinical

\section{Rune J. Ulvik}

rune.ulvik@med.uib.no

Klinisk institutt 2

Det medisinsk-odontologiske fakultet

Universitetet i Bergen

og

Laboratorium for klinisk biokjemi

Haukeland universitetssykehus

\section{Rolf Møller}

Stamina Helse og Trening

Sem

\section{Tor Hervig}

Avdeling for immunologi og transfusjonsmedisin Haukeland universitetssykehus

og

Klinisk institutt 2

Det medisinsk-odontologiske fakultet

Universitetet i Bergen

\section{HOVEDBUDSKAP}

$28 \mathrm{mg}$ hemjern daglig var like effektivt som $100 \mathrm{mg}$ jernsalt for å optimalisere hemoglobinnivået ved jernmangel og lett jernmangelanemi forårsaket av lavt inntak av jern i kosten

Høydosejern var mer effektivt enn lavdosejern for å øke jernlageret

Lavdosejern ble bedre tolerert og ga mindre gastrointestinale bivirkninger enn høydosejern 
RAMME 1

Grenseverdier for jernstatus $(14,15)$

- Normal jernstatus

Kvinner: $\mathrm{Hb} \geq 12,0 \mathrm{~g} / 100 \mathrm{ml}$

Menn: $\mathrm{Hb} \geq 13,5 \mathrm{~g} / 100 \mathrm{ml}$

S-ferritin $\geq 15 \mu \mathrm{g} / \mathrm{l}$ for begge kjønn

- Jernmangel, definert som tomme jernlagre uten anemi

Kvinner: $\mathrm{Hb} \geq 12,0 \mathrm{~g} / 100 \mathrm{ml}$

S-ferritin < $15 \mu \mathrm{g} / \mathrm{l}$ for begge kjønn

- Jernmangelanemi

Kvinner: $\mathrm{Hb}<12,0 \mathrm{~g} / 100 \mathrm{ml}$

Menn: $\mathrm{Hb}<13,5 \mathrm{~g} / 100 \mathrm{ml}$

S-ferritin < $15 \mu \mathrm{g} / \mathrm{l}$ for begge kjønn

research,1994). Blinding ble sikret ved at det $\mathrm{i}$ begge grupper ble gitt en daglig dose på fire tabletter med likt utseende. Lavdosegruppen fikk tre tabletter med totalt $27,6 \mathrm{mg}$ jern, sammensatt av $24 \mathrm{mg}$ ferrofumarat og 3,6 mg hemjern (Hemofer, Cederroth), pluss en placebotablett med utseende som en FerroRetard-tablett. Med «hemjern» menes jerntabletter sammensatt av 11-13\% hemjern og resten jernfumarat. Høydosegruppen
Menn: $\mathrm{Hb} \geq 13,5 \mathrm{~g} / 100 \mathrm{ml}$

fikk en tablett med $100 \mathrm{mg}$ jern som ferrosulfat (FerroRetard, Nycomed Pharma) pluss tre placebotabletter med utseende som Hemofer-tabletter. Tablettene ble lagret ved og utdelt fra sykehusapoteket.

Følgende analyser ble gjort i veneblod ved start og etter henholdsvis to, fire, åtte og 12 uker: Hb, s-ferritin, s-jern og s-jernbindingskapasitet. For å utelukke akuttfasereaksjon ble CRP-nivået analysert ved de samme tidspunkter. Blodprøvene ble analysert med rutinemetoder ved Laboratorium for klinisk biokjemi, Haukeland universitetssykehus. Hemoglobinnivå ble analysert på hematologiinstrumentene Cell-Dyn 4000 (Abbot) og $\mathrm{H}^{*} 2$ (Bayer), begge med en analytisk variasjonskoeffisient på $1 \%$. S-ferritin ble analysert med immunologisk metode (Bayer Immuno 1 system, Technicon), med en analytisk variasjonskoeffisient på 3-5\%. S-jern og s-jernbindingskapasitet ble analysert med henholdsvis kolorimetrisk og immunturbidimetrisk metode (Roche Modular), med en analytisk variasjonskoeffisient på $1-2 \%$.

Deltakerne førte dagbok for registrering av bivirkninger under behandlingen, spesifisert som obstipasjon, diaré, mageknip, kvalme og luftplager. Det ble også notert interkurrent sykdom, bruk av andre medisiner og dager da studiemedisinen ble glemt.

Studien ble godkjent av regional komité

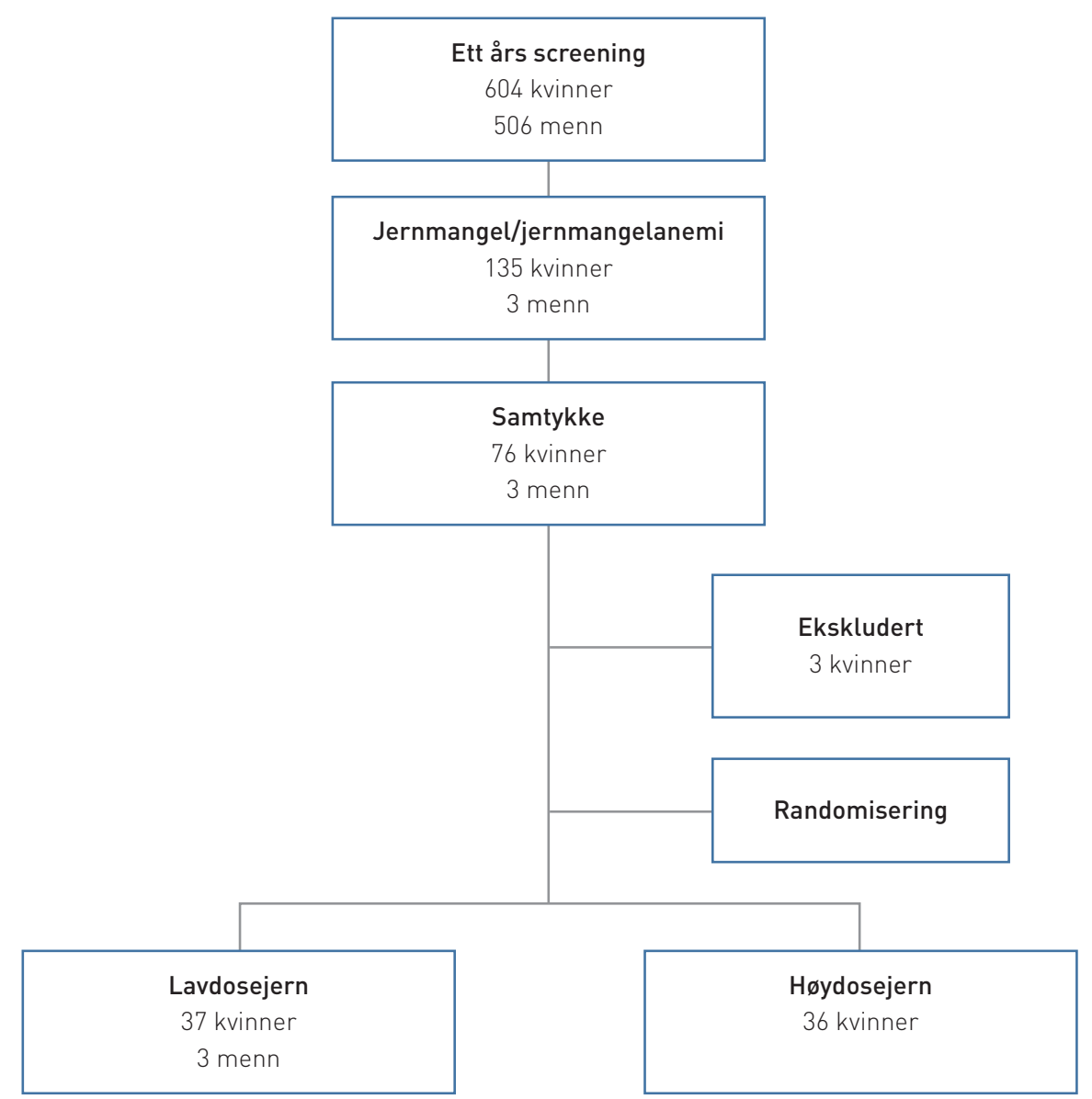

Figur 1 Flytskjema som viser antall kvinner og menn med jernmangel eller jernmangelanemi som ble inkludert i studien og fordelt på to behandlingsgrupper, en som fikk lavdosejern og en som fikk høydosejern for medisinsk og helsefaglig forskningsetikk, Vest-Norge (REK Vest). Deltakerne ga skriftlig, informert samtykke. Studien er ikke registrert fordi den ble utført før krav om registrering ble innført.

\section{Statistikk}

Siden ca. $20 \%$ av kvinner i fertil alder har tomme jernlagre, regnet vi med at det av 600 kvinner som meldte seg som nye blodgivere, ville være rundt 120 med jernmangel, og at med en samtykkeprosent på $70-80 \%$ ville vi kunne inkludere ca. 90 kvinner i studien. Det endelige antall deltakere ble noe lavere enn dette på grunn av lavere samtykkeprosent. Som ventet var antallet menn med jernmangel svært lavt. Med det aktuelle antall deltakere i hver gruppe (fig 1) og et signifikansnivå på 0,05 hadde studien $88 \%$ styrke for å oppdage en forskjell på minst $4 \mu \mathrm{g} / \mathrm{l}(\mathrm{SD} 5,5)$ i s-ferritinnivå mellom gruppene og $77 \%$ for å oppdage en forskjell på minst $0,5 \mathrm{~g} / 100 \mathrm{ml}(\mathrm{SD} 0,8)$ i hemoglobinnivå.

Mann-Whitneys test og Fishers eksakte test ble brukt ved sammenlikning mellom gruppene for henholdsvis kontinuerlige og kategoriske variabler. For beregning av endring av blodprøvene fra utgangsverdi ved de fire måletidspunktene ble det benyttet Wilcoxons signed ranks-test med signifikansgrense $p<0,05 / 4=0,013$, etter Bonferronikorreksjon for multiple sammenlikninger. Hos deltakere som trakk seg fra forsøket pga. bivirkninger av behandlingen, ble siste registrerte verdi benyttet.

\section{Resultater}

Resultatene for deltakere med jernmangel og deltakere med jernmangelanemi er slått sammen. Tabell 1 viser prøveresultatene før behandling. Av totalt 76 deltakere hadde 13 kvinner og én mann jernmangelanemi. Disse er fordelt på behandlingsgruppene som vist i tabell 2.

I høydosegruppen økte medianverdien for ferritin fra 9,5 $\mu \mathrm{g} / \mathrm{l}(95 \% \mathrm{KI} 8-11 \mu \mathrm{g} / \mathrm{l})$ til $22,5 \mu \mathrm{g} / \mathrm{l}(95 \% \mathrm{KI} 19-28 \mu \mathrm{g} / \mathrm{l})(\mathrm{p}<0,001)$, i lavdosegruppen fra $10 \mu \mathrm{g} / 1$ (95\% KI $8-11$ $\mu \mathrm{g} / \mathrm{l})$ til $17 \mu \mathrm{g} / \mathrm{l}(95 \% \mathrm{KI} 14-20 \mu \mathrm{g} / \mathrm{l})(\mathrm{p}<$ $0,001)$. Økningen i ferritinnivå fra start til etter 12 uker var signifikant større i høydosegruppen enn i lavdosegruppen $(p<0,001)$ (fig 2). For de andre blodprøvene var det ikke statistisk signifikant forskjell i endring mellom gruppene i løpet av behandlingsperioden (fig 3-5), men endringene innen gruppene var signifikante. Medianverdien for hemoglobin økte fra $12,5 \mathrm{~g} / 100 \mathrm{ml}(95 \% \mathrm{KI}$ $12,1-12,8 \mathrm{~g} / 100 \mathrm{ml})$ til $12,9 \mathrm{~g} / 100 \mathrm{ml}(95 \%$ KI 12,6-13,2g/100 ml) i høydosegruppen $(\mathrm{p}=0,005) \mathrm{og}$ fra $12,8 \mathrm{~g} / 100 \mathrm{ml}(95 \% \mathrm{KI}$ $12,3-12,9 \mathrm{~g} / 100 \mathrm{ml})$ til 13,2 g/100 ml (95\% KI $12,7-13,4 \mathrm{~g} / 100 \mathrm{ml})$ i lavdosegruppen $(\mathrm{p}<0,001)$. For $\mathrm{s}$-jern var det en signifikant økning $(\mathrm{p}<0,001)$ og for s-jernbindingskapasitet et signifikant fall i medianverdien i løpet av behandlingen $(p<0,001)$. 
21 deltakere i høydosegruppen (58\%) og 14 i lavdosegruppen (35\%) rapporterte symptomer på gastrointestinale bivirkninger $(\mathrm{p}=0,06)$. De fleste hadde lette plager dominert av obstipasjon eller diaré. I begge grupper ble det registrert deltakere som glemte å ta tabletter enkelte dager i løpet av studieperioden. Fem individer måtte avbryte behandlingen på grunn av intolerable bivirkninger, fire $\mathrm{i}$ høydosegruppen og én i lavdosegruppen. Ingen av deltakerne fikk påvist akuttfasereaksjon med økt CRP-nivå i studieperioden.

\section{Diskusjon}

Vi sammenliknet effekten av et daglig tilskudd av en lav dose jern klassifisert som kosttilskudd med effekten av en større farmakologisk og tradisjonell jerndose hos ellers friske individer som fikk påvist jernmangel og lett jernmangeanemi da de for første gang meldte seg som blodgivere. Det ble ikke gjort kostholdsregistrering, men da det ikke ble påvist sykdom hos noen av deltakerne, var lavt inntak av jern i kosten den mest sannsynlige årsaken til dårlig jernstatus. Deltakerne hadde ikke gitt blod og var heller ikke aktive blodgivere i studieperioden. Resultatene fra studien er derfor ikke representative for etablerte blodgivere eller for pasienter med sykdom som fører til negativ jernbalanse.

At jernmangel først og fremst rammer kvinner før menopausen, på grunn av menstruasjonsblødninger, og nærmest er fraværende hos menn (2), ble bekreftet av den store overvekt av yngre kvinner som ble inkludert $\mathrm{i}$ studien. Hos de få deltakerne utenom gruppen av yngre kvinner ble det ikke funnet tegn på sykdom ved inklusjon eller i løpet av studieperioden. Et daglig tilskudd av 27,6 mg hemjern var tilstrekkelig til å normalisere en lett nedsatt erytropoese. Effekten var sammenliknbar med tilskudd av en farmakologisk dose på $100 \mathrm{mg}$ jernsulfat. Ved subnormalt hemoglobinnivå er hastigheten i danning av røde blodceller normal eller bare lett nedsatt og kan ikke forseres ved å gi store jerndoser (7). Det tar 8-12 uker å oppnå et optimalt hemoglobinnivå (fig 3). For å få en økning på ca. 0,5 g/100 $\mathrm{ml}$ må det tilføres en ekstra mengde jern på $70-80 \mathrm{mg}$. Dette kan oppnåes ved å absorbere ca. 1,4 mg ekstra jern per døgn i løpet av åtte uker. Med en absorpsjon på 10-15\% av tilført jerndose er et daglig tilskudd av 27 mg jern tilstrekkelig behandling. Store jerndoser har derfor ingen terapeutisk fordel.

Detakelse i en studie kan i seg selv fungere som en konfunderende variabel, ved at deltakerne bevisst eller ubevisst endrer atferd og livsstil i en retning som påvirker resultatet. Dette er den såkalte Hawthorneeffekten, «en effekt av undersøkelsen i seg selv» (16). I vår studie kunne det tenkes at deltakerne ble mer opptatt av å øke sitt jerninntak via kosten, og at dette kan ha gitt en ukontrollert tilleggseffekt som forbedret
Tabell 1 Deltakere med jernmangel og jernmangelanemi slått sammen til én gruppe og fordelt på to behandlingsgrupper med tilskudd av henholdsvis lavdose- og høydosejern. Tabellen viser alder og prøveresultat (median og spredning) før behandling med henholdsvis lavdose- og høydosejern

\begin{tabular}{lccccc}
\hline & \multicolumn{1}{c}{ Lavdose } & \multicolumn{2}{c}{ Høydose } \\
Antall (kvinner/menn) & 40 & $(37 / 3)$ & 36 & $(36 / 0)$ \\
Alder (år) & 29 & $(18-68)$ & 33 & $(19-52)$ \\
S-ferritin $(\mu \mathrm{g} / \mathrm{l})$ & 10,0 & $(2-14)$ & 9,5 & $(3-14)$ \\
$\mathrm{Hb}(\mathrm{g} / 100 \mathrm{ml})$ & 12,8 & $(10,0-14,1)$ & 12,5 & $(10,6-14,6)$ \\
S-jern $(\mu \mathrm{mol} / \mathrm{l})$ & 12,0 & $(4,1-48,9)$ & 11,2 & $(3,5-35,6)$ \\
S-jernbindingskapasitet $(\mu \mathrm{mol} / \mathrm{ll})$ & 74 & $(52-96)$ & 70 & $(53-93)$
\end{tabular}

Tabell 2 Deltakere med jernmangelanemi fordelt på to behandlingsgrupper med tilskudd av henholdvis lavdose- og høydosejern. Jernmangelanemi er definert med grenseverdier for hemoglobin og s-ferritin som vist i ramme 1. For kvinner er resultatene oppgitt som median (spredningl. For mannen i lavdosegruppen er oppgitt aktuelle prøveverdier

\begin{tabular}{lll}
\hline & Lavdosejern & Høydosejern \\
Antall (kvinner/menn) & $6(5 / 1)$ & $8(8 / 0)$ \\
$\mathrm{Hb}(\mathrm{g} / 100 \mathrm{ml})$ & $\begin{array}{l}\text { Kvinner: } 11,7(10,0-11,9) \\
\text { Mann: } 13,1\end{array}$ & $11,7(10,6-11,9)$ \\
S-ferritin $(\mu \mathrm{g} / \mathrm{l})$ & Kvinner: $5(2-14)$ & $8(3-14)$ \\
& Mann: 7 & \\
\hline
\end{tabular}

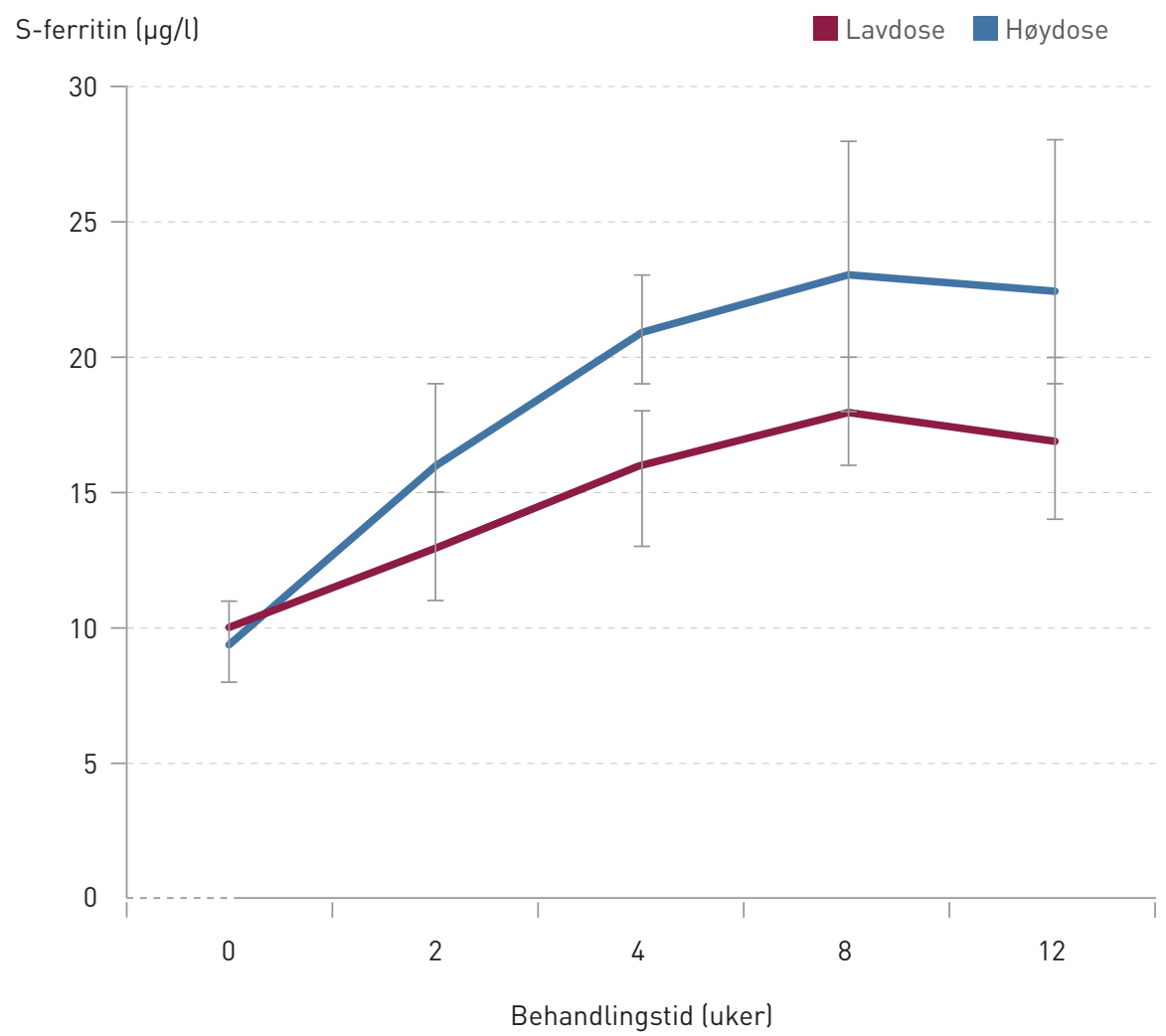

Figur 2 Endring is-ferritinnivå (median og $95 \%$ Kl) ved tilskudd av lavdose- og høydosejern 
$\mathrm{Hb}(\mathrm{g} / 100 \mathrm{ml})$

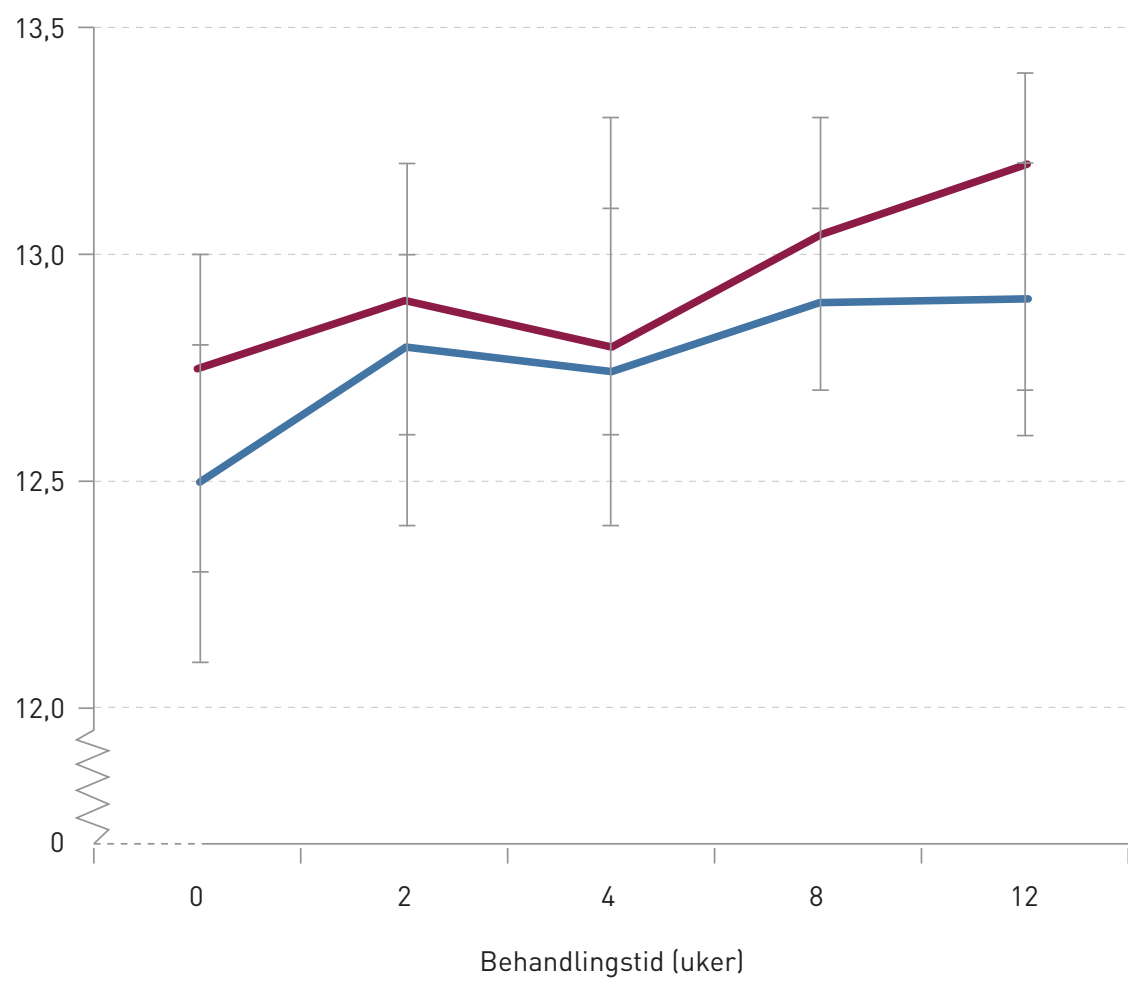

Figur 3 Endring i hemoglobinnivå (median og $95 \%$ KI) ved tilskudd av lavdose- og høydosejern

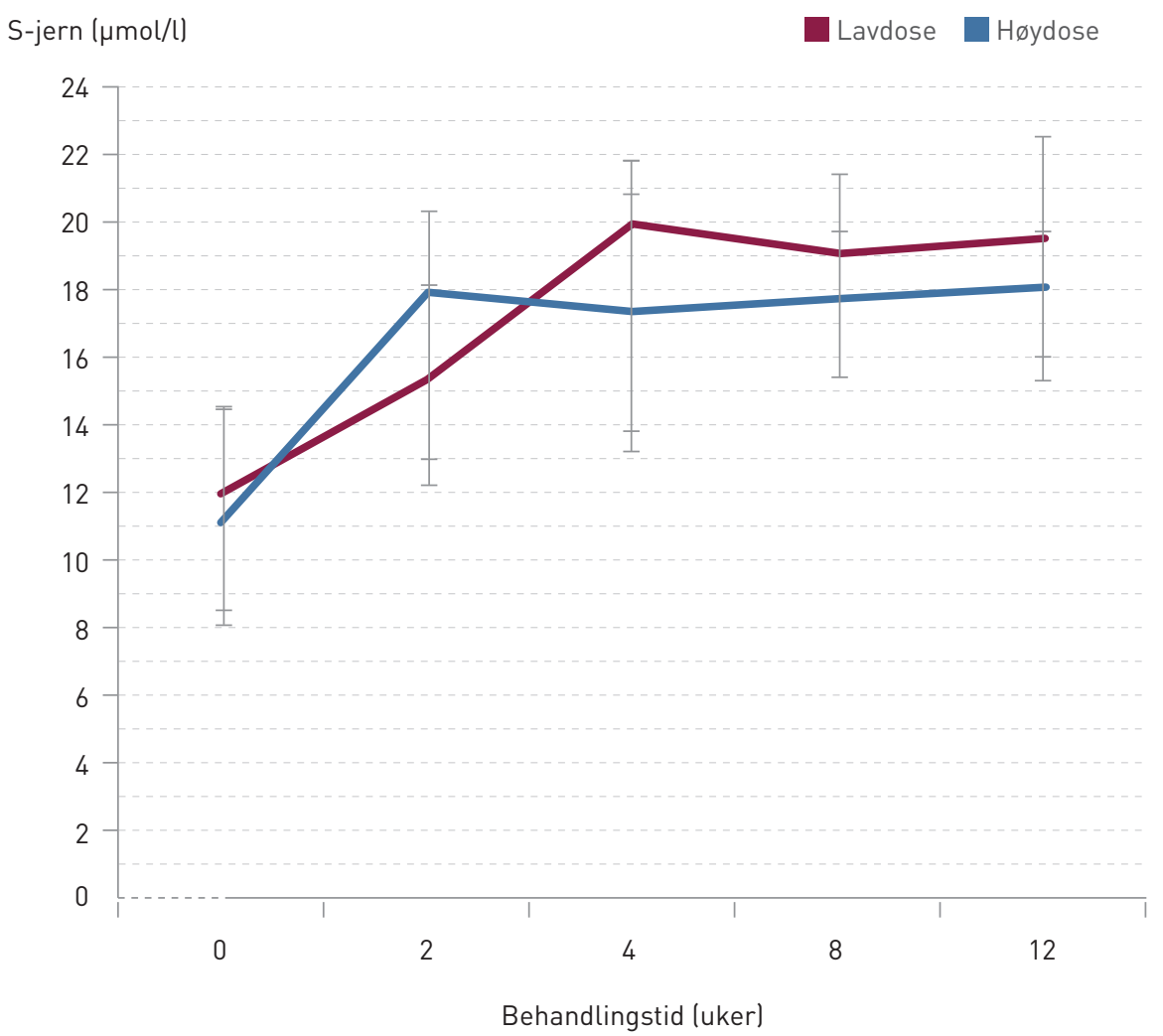

Figur 4 Endring is-jernnivå (median og $95 \%$ KI) ved tilskudd av lavdose- og høydosejern jernstatusen. Kostholdsendringer ble ikke registrert, men hvis det forekom, ville vi forvente at det var likt fordelt $i$ de to gruppene og derfor ikke ville gi noen systematisk skjevhet i sammenlikningen mellom dem.

I begge dosegrupper steg s-ferritinnivået som tegn på økning av jernlageret, men økningen fra utgangsverdien var nesten dobbelt så stor i høydosegruppen som i lavdosegruppen. Økningen i s-ferritinnivå flatet ut etter åtte uker i begge grupper, som uttrykk for at prosentvis absorpsjon av jern er omvendt proporsjonal med størrelsen på jernlagrene. Bezwoda og medarbeidere viste at denne effekten inntreffer allerede når $\mathrm{s}$-ferritinnivået øker fra 5-10 $\mu \mathrm{g} / \mathrm{l}$ (17). Tilsvarende dose-effekt-påvirkning på s-ferritinnivået av lave doser hemjern ble vist $\mathrm{i}$ en studie hvor kvinner med et s-ferritinnivå $\leq 20 \mu \mathrm{g} / \mathrm{l}$ fikk et daglig tilskudd av henholdsvis $9 \mathrm{mg}$ og $27 \mathrm{mg}$ hemjern (10). Begge grupper fikk samme gjennomsnittlige Hb-økning på $0,6 \mathrm{~g} / 100 \mathrm{ml}$ i løpet av en måned og med begge jerndoser nådde s-ferritinnivået et platå etter $4-5$ uker, men den høyeste dosen ga ca. $30 \%$ større økning.

Også Borch-Iohnsen og medarbeidere fant at hos kvinner med små eller tomme jernlagre som i seks måneder fikk et daglig tilskudd av $18 \mathrm{mg}$ jern hemjern, økte s-ferritinnivået mest de første fire ukene, men økningen fortsatte langsomt også resten av behandlingsperioden (9). I denne studien var $20 \%$ av kvinnene blodgivere, noe som kan ha ført til at gjenopprettelse av jernlagrene tok lengre tid.

Vårt lavdosealternativ hadde bare $28 \%$ jerninnhold sammenliknet med høydosejern. Forskjellen i effekt mellom preparatene var imidlertid mindre enn doseforskjellen skulle tilsi. Innhold av hemjern i lavdosetabletten kan ha betydning, da prosentvis absorpsjon av hemjern er betydelig større enn absorpsjon av jernsalt, henholdsvis $20-30 \%$ og $4-12 \%$, både fra kosten og fra jerntabletter $(18,19)$. Prosentvis absorpsjon av jern fra ferrosulfat og ferrofumarat er imidlertid den samme (20).

Bivirkninger av jern avhenger av dosestørrelse, og det var derfor ikke uventet at den laveste jerndosen ga færre plagsomme bivirkninger. Men hemjern tolereres også bedre fordi det er et fysiologisk, ikke-reaktivt molekyl. Jernsalt, derimot, ioniseres og reagerer med kostfaktorer i tarmlumen samtidig som det fører til økt oksidativt stress og toksiske reaksjoner i tarmmucosa. De kjemiske egenskapene til jernsalt forklarer således både varierende absorpsjonsgrad og smertefulle bivirkninger $(21,22)$.

I litteraturen er det betydelig variasjon i grenseverdiene for s-ferritin og hemoglobin $(15,23)$. Vi valgte å bruke en grenseverdi for hemoglobin anbefalt av Centers for Disease Control (ramme 1) (14). For s-ferritin er grenseverdien relatert til mangel på fargbart jern i margutstryk, som er gullstandard for jernmangel definert som tomme jernlagre. Hallberg og medarbeidere viste at s-ferritin 
S-jernbindingskapasitet $(\mu \mathrm{mol} / \mathrm{l})$

Lavdose

Høydose

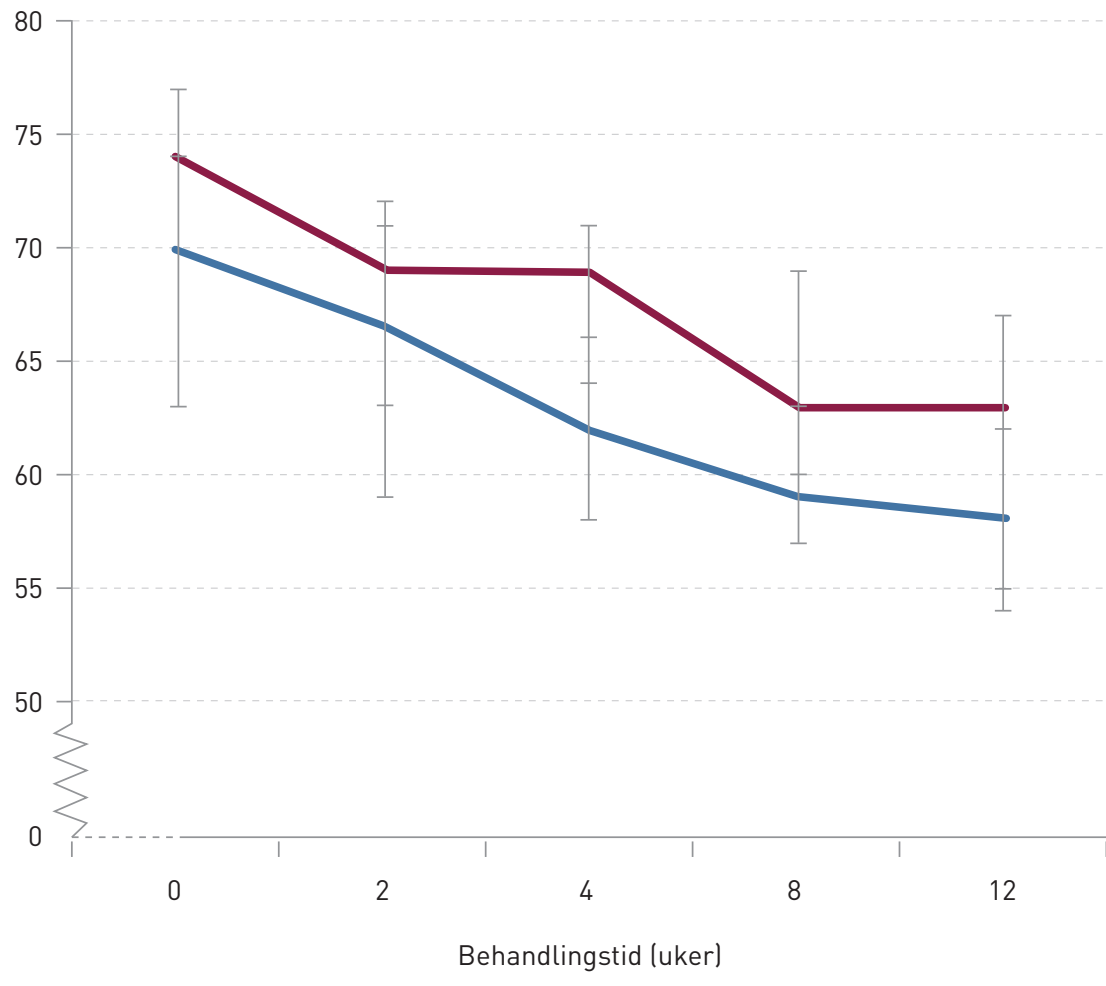

Figur 5 Endring i s-jernbindingskapasitet (median og $95 \%$ KI) ved tilskudd av lavdose- og høydosejern

$<15 \mu \mathrm{g} / \mathrm{l}$ ga korrekt klassifisering av $91-95 \%$ av kvinner som ikke hadde fargbart jern i beinmargsutstryk (15). Likeledes viste Guyatt og medarbeidere i en større metaundersøkelse at $\mathrm{s}$-ferritin $\leq 15 \mu \mathrm{g} / \mathrm{l}$ ga en sannsynlighetsratio for jernmangel på 51,9 (24). Det betyr at sannsynligheten for å få en s-ferritinverdi lik eller mindre enn grenseverdien er 51,9 ganger større dersom pasienten har jernmangel enn om han ikke har jernmangel. Generelt gjelder at hvis et positivt prøvesvar har en sannsynlighetsratio på $>10$, er det stor sannsynlighet for sykdom (25). Valg av grenseverdi på $15 \mu \mathrm{g} / \mathrm{l}$ for s-ferritin ga således en høy spesifisitet for jernmangel, hvilket er et viktig kriterium for en effektstudie.

Vi takker Torfinn Hansen for hjelp med statistisk bearbeiding av materialet. Likeledes takkes Cederroth AS og Nycomed Pharma, som har gitt jerntablettene til studien, samt Liv Wie, Sykehusapoteket, Haukeland universitetssykehus, som har vært ansvarlig for lagring og distribusjon av jerntabletter.

\section{Rune J. Ulvik (f. 1947)}

er spesialist i medisinsk biokjemi. Han er professor i medisinsk biokjemi ved Klinisk institutt 2 og overlege ved Laboratorium for klinisk biokjemi. Forfatter har fylt ut ICMJE-skjemaet og oppgir følgende interessekonflikter: Han har mottatt honorar for foredrag og reisestøtte fra Cederroth AS.

\section{Rolf Møller (f. 1962)}

er bedriftslege ved Stamina Helse og Trening i Tønsberg.

Forfatter har fylt ut ICMJE-skjemaet og oppgir følgende interessekonflikter: Han har mottatt honorar for foredrag og reisestøtte fra Cederroth AS.

\section{Tor Hervig (f. 1954)}

er spesialist i immunologi og transfusjonsmedisin. Han er overlege ved Avdeling for immunologi og transfusjonsmedisin og professor i transfusjonsmedisin ved Klinisk institutt 2 Forfatter har fylt ut ICMJE-skjemaet og oppgir ingen interessekonflikter.

\section{Litteratur}

1. Hercberg S, Preziosi P, Galan P. Iron deficiency in Europe. Public Health Nutr 2001; 4 (2B): 537-45.

2. Røsvik AS, Hervig T, Wentzel-Larsen T et al. Iron status in Norwegian blood donors: comparison of iron status in new blood donors registered in 1993-1997 and in 2005-2006. Vox Sang 2009; 96: 49-55.

3. Borch-lohnsen B, Sandstad B, Åsberg A. Iron status among 3005 women aged $20-55$ years in Central Norway: the Nord-Trøndelag Health Study (the HUNT study). Scand J Clin Lab Invest 2005; 65 : $45-54$

4. Ioannou GN, Rockey DC, Bryson CL et al. Iron deficiency and gastrointestinal malignancy: a population-based cohort study. Am J Med 2002 . 113: $276-80$.

5. Schiøtt J. Ulike doseringsanbefalinger for jern. Norsk Farmaceutisk Tidsskrift 2009; nr. 11: 21.

6. Norsk legemiddelhåndbok for helsepersonell. L4.1 Legemidler mot anemi, L4.1.1.1 Jern II-verdig til peroral administrasjon. Oslo: Norsk legemiddelhåndbok for helsepersonell, 2010: 903-4. www.legemiddelhandboka.no (18.2.2013).

7. Crosby WH. The rationale for treating iron deficiency anemia. Arch Intern Med 1984: 144: 471-2.

8. Hallberg L, Ryttinger $L$, Sölvell L. Side-effects of oral iron therapy. A double-blind study of different iron compounds in tablet form. Acta Med Scand Suppl 1966; 459: 3-10.

9. Borch-lohnsen B, Meltzer HM, Stenberg V et al. Bioavailability of daily low dose iron supplements in menstruating women with low iron stores. Eur J Clin Nutr 1990; 44: 29-34.

10. Fogelholm M, Suominen M, Rita H. Effects of lowdose iron supplementation in women with low serum ferritin concentration. Eur J Clin Nutr 1994 48: 753-6.

11. Borch-lohnsen B, Halvorsen R, Stenberg V et al. The effect of daily low-dose iron supplements in female blood donors with depleted iron stores: comparison with female non-donors. Scand J Clin Lab Invest 1993; 53: 789-91.

12. Eskeland B, Malterud K, Ulvik RJ et al. Iron supplementation in pregnancy: is less enough? A ran domized, placebo controlled trial of low dose iron supplementation with and without heme iron. Acta Obstet Gynecol Scand 1997; 76: 822-8.

13. Forskrift om kosttilskudd. Nr. 755. FOR 2004-0520. Oslo: Sosial- og helsedepartementet, 2004.

14. Recommendations to prevent and control iron deficiency in the United States. Centers for Disease Control and Prevention. MMWR Recomm Rep 1998; 47 (RR-3): 11-4

15. Hallberg L, Bengtsson C, Lapidus L et al. Screening for iron deficiency: an analysis based on bonemarrow examinations and serum ferritin determinations in a population sample of women. $\mathrm{Br}$ J Haematol 1993; 85: 787-98.

16. Store norske leksikon. Hawthorne-effekt. http://snl.no/Hawthorne-effekt (18.2.2013)

17. Bezwoda WR, Bothwell TH, Torrance JD et al. The relationship between marrow iron stores, plasma ferritin concentrations and iron absorption. Scand J Haematol 1979; 22: 113-20.

18. Björn-Rasmussen E, Hallberg L, Isaksson B et al. Food iron absorption in man. Applications of the two-pool extrinsic tag method to measure heme and nonheme iron absorption from the whole diet. J Clin Invest 1974; 53: 247-55.

19. Ekman M, Reizenstein P. Comparative absorption of ferrous and heme-iron with meals in normal and iron deficient subjects. Z Ernahrungswiss 1993; 32: 67-70.

20. Harrington M, Hotz C, Zeder C et al. A comparison of the bioavailability of ferrous fumarate and ferrous sulfate in non-anemic Mexican women and children consuming a sweetened maize and milk drink. Eur J Clin Nutr 2011; 65: 20-5

21. Zijp IM, Korver O, Tijburg LB. Effect of tea and other dietary factors on iron absorption. Crit Rev Food Sci Nutr 2000; 40: 371-98.

22. Troost FJ, Saris WH, Haenen GR et al. New method to study oxidative damage and antioxidants in the human small bowel: effects of iron application. Am J Physiol Gastrointest Liver Physiol 2003; 285: G354-9.

23. Fairbanks VF, Tefferi A. Normal ranges for packed cell volume and hemoglobin concentration in adults: relevance to 'apparent polycythemia'. Eur J Haematol 2000; 65: 285-96.

24. Guyatt GH, Oxman AD, Ali M et al. Laboratory diagnosis of iron-deficiency anemia: an overview. J Gen Intern Med 1992; 7: 145-53.

25. Peat J, Barton B Medical statistics. A guide to data analysis and critical appraisal. Oxford: Blackwell, 2005: 285-6

Mottatt 7.2. 2011, første revisjon innsendt 14.11 2011, godkjent 18.2. 2013. Medisinsk redaktør Trine B. Haugen. 